REVISTA de

PEDAGOGIE

\title{
ALINA GHIMIȘ. ALYA AND THE MUSIC BOX. \\ Bucharest, Sigma Publishing, 2019 (volumes 1-3)
}

ALINA GHIMIȘ. ALYA ȘI CUTIA MUZICALĂ. București, Editura Sigma, 2019 (vol. 1-3)

\section{Ligia SARIVAN}

Journal of Pedagogy, 2020 (2), 237 - 238

https://doi.org/10.26755/RevPed/2020.2/237

\section{(c) (1) (8)(2)}

This work is licensed under the Creative Commons Attribution-NonCommercial-ShareAlike 4.0 International License. 94042, USA.

Published by:

Centrul Național de Politici și Evaluare în Educație

UNITATEA DE CERCETARE ÎN EDUCAȚIE

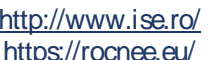

Further information about Revista de Pedagogie - Journal of Pedagogy can be found at: 
ALINA GHIMIŞ. ALYA ŞI CUTIA MUZICALĂ. Colec ia Comoara cu virtu i. Bucureşti, Editura SIGMA, 2019

\section{Ligia Sarivan*}

Centrul Na ional de Politici şi Evaluare în Educa ie, Unitatea de Cercetare în Educa ie,

Bucureşti, România

ligia.sarivan@ise.ro

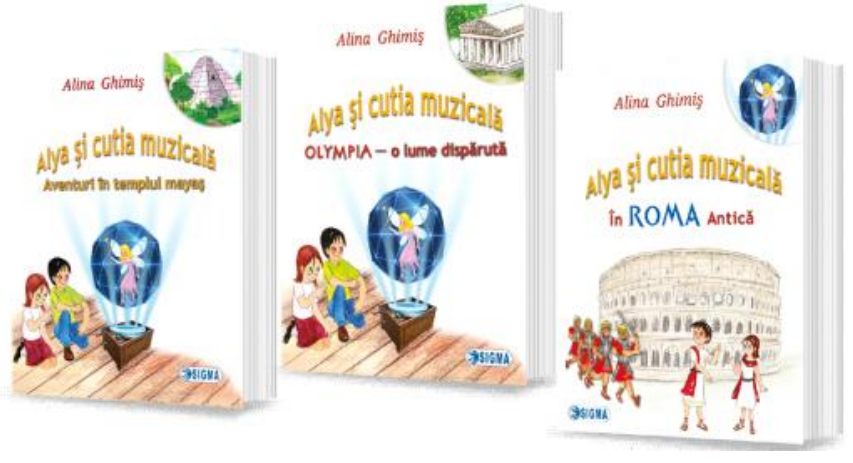

Apărută la Editura Sigma începând cu vara 2019, Alya şi cutia muzicală reprezintă o serie dedicată micilor cititori, iscoditori, căutători de comori... de cunoaştere!

Prezentând un text după tehnica povestirii în ramă, ,Alya...” este concepută în opt episoade, până acum apărând trei dintre acestea. Personajele recurente sunt doi fra i - Teo şi Timeea, precum şi zâna Alya care este captivă într-o cutie muzicală, în urma unui blestem. Pentru a o elibera, cei doi copii călătoresc în timp şi în spa iu, în fiecare volum vizitând o civiliza ie străveche şi întorcându-se acasă cu câte un indiciu necesar eliberării Alyei. La capătul celor opt episoade, cele opt indicii vor oferi formula de ştergere a blestemului.

* Cercetător ştiin ific dr., Centrul Na ional de Politici şi Evaluare în Educa ie, Unitatea de Cercetare în Educa ie, Bucureşti, România. 
Cei doi copii sunt ataşan i, cu pasiuni şi personalită i complementare, oferind astfel cititorului multiple ocazii de identificare. Itinerariile parcurse reprezintă oportunită i pentru descoperirea unor lumi apuse: în primele trei volume Teo şi Timeea intră într-un templu mayaş, ajung la Olympia pe vremea jocurilor antice şi într-o celebră şcoală de gladiatori de la Roma. De fiecare dată, ei trec prin aventuri şi încercări care le solicită inventivitatea şi rezolvarea de probleme practice; în fiecare episod sunt ajuta i şi ajută pe cineva, după un model similar basmelor. Diferen a este dată de situarea celor doi copii în lumea contemporană şi de călătoriile în timp. Chiar dacă acestea au loc cu un mijloc de transport magic (un cufăr fermecat!) „Alya..." nu este un basm clasic, căci îi lipseşte atemporalitatea. Ancorarea în lumea de azi - acasă reprezintă o casă din zilele noastre, într-o localizare obişnuită - şi excursiile în timp dau poveştii caracterul de modernitate, cu priză la publicul tânăr.

„Alya...” este literatură fantasy de bună calitate, motivantă pentru cei mici. Dincolo de lumile imaginare pe care le deschide, seria aduce multe informa ii cu caracter istoric şi cultural, extinzând universul de cunoaştere al cititorului. Ca un supliment pentru... bună purtare şi educare (sic!), copiii descoperă la finalul fiecărui volum jocuri şi probleme distractive legate de textul citit şi un set de întrebări pentru orientarea unei reflec ii de profunzime asupra textului citit.

Seria „Alya şi cutia muzicală” face parte din Colec ia Comoara cu virtu $i$, ini iată la Editura Sigma pentru a sprijini o educa ie centrată pe promovarea binelui, frumosului şi adevărului.

The online version of this article can be found at: http://revped.ise.ro/category/2020-en/

\section{(cc) $\mathrm{EY}-\mathrm{NC}-\mathrm{SA}$}

This work is licensed under the Creative Commons Attribution-NonCommercial-ShareAlike 4.0 International License.

To view a copy of this license, visit http://creativecommons.org/licenses/by-nc-sa/4.0/ or send a letter to Creative Commons, PO Box 1866, Mountain View, CA 94042, USA.
Versiunea online a acestui articol poate fi găsită la: http://revped.ise.ro/category/2020-ro/

\section{$(c c))$ BY-NC-SA}

Această lucrare este licen iată sub Creative Commons Attribution-NonCommercial-ShareAlike 4.0 International License.

Pentru a vedea o copie a acestei licen e, vizita $i$ http://creativecommons.org/licenses/by-nc-sa/4.0/ sau trimite i o scrisoare către Creative Commons, PO Box 1866, Mountain View, CA 94042, SUA. 